\title{
Az önvezető autózás kihívásai és biztonsági kérdései a digitális államban
}

\author{
Zöldy Máté*, Szalay Zsolt, Török Árpád \\ Budapesti Múszaki és Gazdaságtudományi Egyetem, Gépjármútechnológia Tanszék, Budapest \\ Beérkezett: 2020. október 18.; Elfogadva: 2020. október 27.
}

\begin{abstract}
Összefoglalás
A XXI. század első felében a korábban sok évtizeden keresztül lassan változó közlekedés gyorsított ütemben alakul át. Ez alatt a pár év alatt több változás következik be, több kihívást kell leküzdeni, mint a korábbi időszakban. Az elektromos hajtás térnyerése, új jármúhasználati módok mellett a jármúvek autonomizálódása és összekapcsolódása jelenti az új irányokat, amelyek kihívás elé állítják nemcsak az autóipart, hanem a jármúvek használóit és a szabályzókat, az államot is. Kutatásainkban az önvezetô autózás jelentette kihívásokat emeljük ki a többi, röviden bemutatott trend közül, majd pedig vizsgáljuk, milyen kihívásokat támaszt a digitalizálódó állam felé az önvezetés felé elmozduló jármúves technológia.
\end{abstract}

Kulcsszavak: önvezetó autózás, kihívások, szabályozás, sérülékenység, cyber security

\author{
Challenges and safety, security questions of autonomous vehicles \\ in the digital state \\ Máté Zöldy*, Zsolt Szalay, Árpád Török \\ Budapest Technical and Economic University, Faculty of Transportation Engineering and Vehicle Egngineering, \\ Budapest, Hungary
}

\begin{abstract}
Summary
In the first half of the 21 st century, transportation that has been slowly changing over many decades has been transforming at an accelerated rate. Over the course of these few years, there will be more changes and more challenges to overcome. For a century it was unquestionable that a vehicle is driven by a driver and its energy comes via diesel or petrol from crude oil. Today vehicles' autonomy in driving is increasing, and instead of crude oil based fuels first biocomponents and gaseous fuels appeared, and now electricity knocks at the door. The proliferation of the electric driving, the new modes of vehicle use, and the autonomy and connectivity of vehicles represent new directions that challenge not only the automotive industry, but also vehicle users and regulators, and the states. New technologies bring about new security and safety challenges as well. Most of the challenges pop up in the cyber security domain. And its result is that a closer cooperation is necessary between the automotive industry and informatics. As these two leading industrial fields have a different setup, the cooperation is energy demanding task for all participants. Modification and upgrade of the homologation process seems to be one of the potential gateways that could merge the safety requests. Improving traditionally rigid automotive homologation processes needs a lot of extended test opportunities. In our research, we highlight the challenges posed by self-driving cars and show some trends briefly, and then examine the challenges posed by vehicle technology moving towards self-driving, and towards digitizing. The certification process of the automotive industry is highlighted and modifications are proposed. We propose to extend the traditional proving ground based certification processes with special, autonomous vehicles designed processes that are partially made within the virtual reality-proving ground mixtures. A newly designed proving ground not only offers a wide range of vehicle and traffic tests for conventional, connected and automated vehicles, but can also be used to test possible prototype solutions, as well as helps to develop the type-approval process, and useful for educational purposes. Cyber security has special dimensions, newly developed test environment is necessary to validate the vehicles and their elements. A complete vehicle testing and validation center is proposed to establish for automotive cyber security features, focusing not only on known, but also on unknown vulnerabilities. It will help to develop dedicated tests to eliminate unknown vulnerabilities and potential new vulnerabilities.
\end{abstract}

Keywords: self-driving, challenges, regulation, vulnerability, cyber security 


\section{Bevezetés}

Az okostelefonok megjelenése - amely tulajdonképpen tekinthető a korábbi asztali számítógép és a vonalas telefon integrálódásának - már előrevetítette, hogy hamarosan a közlekedés területén is nagy változások várhatók (Zöldy 2016). Az ezredforduló környékén a tudományos társadalom még a bioüzemanyagok elterjedésében látta a legnagyobb fejlődési potenciált. Bioetanol- és biodízelgyárak épültek, és hamarosan elkezdődött ezek bekeverése az üzemanyagokba (Zöldy 2009). A trend messze nem követte a várakozásokat, bár még manapság is a motorhajtóanyagok fontos komponensei a bio- és más alternatív üzemanyagoknak, a jármúipar figyelme a hibrid jármúvek, majd az utóbbi években az elektromos autózás felé fordult (Emőd et al. 2006). Bár már a XIX-XX. század fordulóján is volt elektromos autózás, a kőolajtermékek árának csökkenése és könnyú kezelhetősége majd 100 évre visszavetette az elektromos áram közlekedési célú, széles körü használatát. Az elmúlt évek óriási várakozásai is részben teljesülnek csak, amelynek egyik oka a jármúvek akkumulátorainak nagy gyártási költsége és nehézkes tölthetősége. Másik oldalon az infrastruktúra hiánya az, amely hátráltatja az elektromobilitás térnyerését (Csiszár 2019).

Az elektrotechnika, szenzorika és a számítástechnika fejlődése folytán a jármúvekben egyre több érzékelő, feldolgozó és beavatkozó egység jelent meg. Elterjedtek a vezetéstámogató rendszerek, amelyek fó alkalmazási okai a biztonság növelése és a kényelmi funkciók bővítése volt (Rödönyi 2014). Ezek a rendszerek egyre magasabb szintet értek el, és összekapcsolásuk révén a jármúvezető támogatása mellett esetenként, majd egyre több esetben, a jármúvezető szerepének az átvétele valósul meg. Kutatásaink ez utóbbi területre, az önvezető jármúvek fejlesztésére fókuszálnak és igyekeznek feltárni a jármúvek használatbavételéhez szülkséges ún. homologációs eljárások és tesztek kritikus pontjait, illetve erre fejlesztési javaslatokat is kínálnak.

\section{Irodalmi áttekintés}

A hagyományos homologizációs folyamat fó mozgatórugója annak biztosítása, hogy csak a biztonságos jármüvek vehessenek részt a közúti forgalomban. A járműnek egy meghatározott piacra történő bevezetése érdekében a gyártónak hivatalosan gondoskodnia kell a jármútípus

1. táblázat |A jármú megfelelőségének jelzésére szolgáló hivatalos módszerek

\begin{tabular}{lll}
\hline Módszernév & Tanúsító & Példák \\
\hline Típusjóváhagyás & kormány & EU, Kína, India \\
\hline Ön-tanúsítás & gyártó & USA, Kanada \\
\hline $\begin{array}{l}\text { Kombinált önbizonyít- } \\
\text { vány és típusjóváhagyás }\end{array}$ & kombinált & Brazília \\
\hline
\end{tabular}

Forrás: (Zöldy 2018) jóváhagyatásáról vagy annak megerősítéséről, különös tekintettel a vonatkozó szabályozási szabványoknak és specifikációnak való megfelelőségre. Világszerte három módszer létezik (Zöldy 2018) annak tanúsítására, hogy egy újonnan forgalomba helyezendő jármútípus megfelel-e az adott térségben meghatározott szabályozási előírásoknak (1. táblázat).

1958-ban a hozták létre a Jármúves Szabályok Harmonizálásának Világfórumát (WP 29) az élenjáró belső égésű motorokat gyártó országok. Az ilyen jellegû harmonizált szabályozások kézzelfogható pozitív hatást gyakorolnak a közlekedés biztonságára, a környezetvédelemre vagy akár a kereskedelemre is. A WP 29 csoport kezeli a típusjóváhagyási, illetve homologációs típusú eljárásokat. Az ENSZ-EGB megközelítése szerint független, harmadik fél által kell a tanúsítási folyamatot elvégezni és az újonnan forgalomba helyezendő jármútípust jóváhagyni (típusjóváhagyás), a másik véglet az autó gyártójának (OEM-nek) önhitelesítése. Ennek során az OEM, mint a jármú gyártója kijelenti, hogy a jármú megfelel/megfelel a jogszabályok listájának, és kijelenti, hogy a közúti forgalom számára biztonságos.

A típusjóváhagyási folyamatot egy OEM-től független szervezet végzi, például a TUV, vagy a DEKRA; akik igazolhatják, hogy az alkatrész/termék megfelel az érvényes előírásoknak és készen áll a forgalomba helyezésre. Ezt a megközelítést föként az EU-ban, Indiában és Kínában használják. Az önhitelesítés elsősorban a termékfelelősséggel kapcsolatos aggályok vizsgálatára irányuló eljárás, amely leginkább az Egyesült Államokban alkalmazott megközelítés. Ez a gyártó által kiadott tanúsításon alapul, amely garantálja, hogy a termék megfelel minden vonatkozó szabványnak.

A típusjóváhagyás ellentmondása a fejlesztés korai szakaszában az, hogy a hatósági és a szabályozási oldalon hiányoznak a technológiával kapcsolatos ismeretek. Nincsenek általánosan elfogadott tesztelési módszerek és tisztázott folyamatok, amelyek lehetővé teszik a típusjóváhagyást. A helytelen szabályozás az innováció blokkolásának következménye lehet. Valójában a tudás olyan innovatív ipari szereplők által jön létre, amelyek versenyeznek egymással a piaci pozíciókért. Az öntanúsítás rendszer magában hordozza a közbiztonság szabályozási keret nélkül történő befolyásolhatóságát, kockázatát. Jó megközelítésnek túnik, amikor az ipari intenzív vállalatok innovációs tevékenységet folytatnak, de egy biztonságos szabályozási rendszer által határolt kereteken belül. Tulajdonképpen, ez történt Magyarországon 2017-ben (Tettamanti et al. 2016).

\section{Autonóm jármúvek jelentette kihívások}

A korszerú mély neurális hálózatok, például az autonóm jármúvekben alkalmazott rendszerek, óriási számítási kapacitást igényelnek. A számítási képesség folyamatosan növekszik, manapság egyetlen számítógép, amelyet fejlesztési célok tesztelésére használtak, elérheti a világ 
2010-es vezetô szuperszámítógépeinek számítási teljesítményét. Noha ez a fejlődés történelmi léptékben is egyedi (Sabjanics 2010), ezzel párhuzamosan nő a legújabb neurális hálózatok számítási igénye.

A számítási teljesítmény iránti növekvő igény különösen igaz a biztonsági szempontból kritikus rendszerekre, például az önvezetô jármúvekre. Az autonóm autók esetében az érzékelési igény pontossága határozottan nagyobb, mint más iparágakban. Ezeknek a rendszereknek tökéletesen kell múködniük, függetlenül az útfelület minőségétôl, a láthatóságtól vagy az időjárási körülményektől (Pinchon et al. 2018).

A neurális hálózatokat reprezentatív adatkészleteken kell tanítani, hogy elérjék a szükséges megbízhatósági szintet. A felhasznált adatbázisoknak lehetőség szerint tartalmazniuk kellene az összes lehetséges vezetési, forgalmi, helyzet- és meteorológiai állapotmintát. Az előzetes számítás szerint szükség esetén a memóriaszükséglet akár száz petabájt tárolókapacitást is elérhet (Grzywaczewski 2017). Ezenkívül, a mély neurális hálózatoknak megfelelő számú paraméterrel kell rendelkezniük, hogy hatalmas adatbázisokból tanulhassanak anélkül, hogy elveszíthetnék saját korábbi tapasztalataikat (Goodfellow et al. 2016). Például, az adatbázis attribútumainak növekedése esetén a korábbi teljesítményszint eléréshez szükséges a számítási kapacitások négyzetes növelése, amely valódi sokrétú mérnöki kihívásként azonosítható. Egyetlen grafikus feldolgozóegységen történő tanítás akár évekbe is kerülhet, eltolva a betanítási folyamat befejezését, a neurális hálózat belső kialakításától függően. Nemcsak a tanítási/tanulási folyamatot kell figyelembe venni, hanem a hálózatépítést, a tárolást és az algoritmust is.

$\mathrm{Az}$ autonóm és összekapcsolt jármúvekben alkalmazott mély neurális hálózatok számítási követelményei óriásiak. Mintaszámítások (Grzywaczewski 2017) alapján

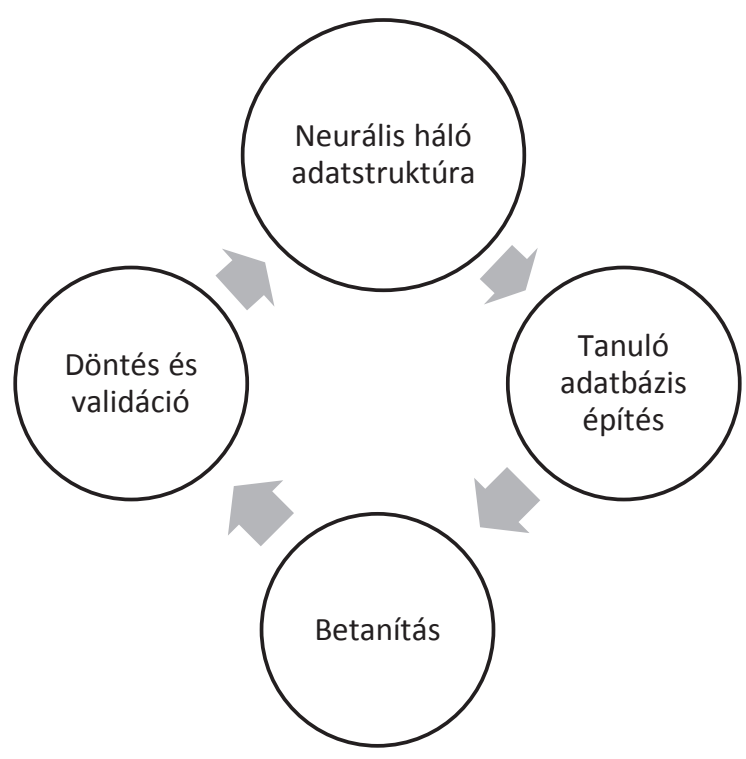

1. ábra Neurális hálózatok felhasználásának egyesített folyamata az önjáró autókban elmondható, hogy az önvezető jármúvek fejlesztése és kutatása nagyszámú grafikus feldolgozó egység felhasználását fogja szükségessé tenni.

Ezzel az óriási számítási igénnyel szerencsére olyan korban szembesülünk, amikor a történelem során először rendelkezésre áll a szükséges számítási teljesítmény. Ennek köszönhetően olyan összetett folyamatokat támogathatunk, mint például az önvezető jármúvek neurális hálózatokon alapuló döntéshozatali folyamatai. A szükséges erőforrások csak egy korlátos részét allokálhatjuk a számítási teljesítmény fedezésére. Komoly erőfeszítésekre van szükség a mély neurális hálózatok, valamint az autóipari adatgyújitési és -felhasználási lehetőségek optimalizálása érdekében (Wang et al. 2018).

Mint az 1. ábra mutatja, erőteljesen integrált folyamat szükséges a mesterséges intelligencia és az automatizált jármúvek összekapcsolásához. A mély neurális hálózatok belső struktúrájának és alkalmazhatóságának megértése kulcsfontosságú a hatékony betanítási adatkészletek létrehozásához. A terepen szerzett adatok képezik a neurális hálózatok tanításának alapját, a jól betanított hálózatok pedig a kulcsai a biztonságos és jó döntések meghozatalának az utakon.

A Bécsi Egyezmény értelmében az autonóm jármúvek közutakon történő tesztelése korlátozott Európában. Fentiek értelmében, egy emberi vezetônek mindig tartózkodnia kell a jármúben, és képesnek kell lennie arra, hogy átvegye a jármú irányítását. Az járműipari fejlesztési folyamatok során a jármúvek zárt tesztpályákon történő tesztelése és fejlesztése általánosnak mondható, ám a meglévő tesztpályák elsősorban a hagyományos jármúvek vizsgálatára használhatók, és nem rendelkeznek olyan speciális létesítményekkel, melyek az önvezető jármúvek speciális tesztelését tennék lehetővé. A hazai ZalaZONE tesztpályához hasonló, az önvezető jármüvek tesztelését magas szinten támogató pályából meglehetősen kevés van a világban, egyedül az Egyesült Államok (MCity) rendelkezik hasonló, releváns létesítményekkel (Szalay et al 2019).

A mesterséges intelligencia gyökerei az informatikai szektorban találhatók. A jármúipari alkalmazásukhoz, azonban kulcsfontosságú, hogy az autonóm jármúvekbe való beépüléskor megfeleljenek a biztonságkritikus rendszerekkel szemben támasztott elvárásoknak. Ez egy jelentős szakadék napjainkban, amelyet meg kell szüntetni, illetve az egyik legnagyobb kihívás az AI rendszerek autóiparban történő megvalósítása.

Az említett kihívásokon túl feltétlen megemlítendő, hogy a környezeti körülményekhez való igazodás továbbra is komoly kihívást jelent az önvezető jármúvek számára. A jármúvekben található érzékelők az emberi szemhez hasonlóan múködnek tiszta időben, így ködben, esőben vagy hóban nem kellően megbízhatóak. Az önvezető jármúvek különleges körülmények közötti tesztelésére megoldást a kritikus incidensek számának minimalizálása terén. 


\section{Javasolt megoldás}

$\mathrm{Az}$ autonóm jármúvek és a mesterséges intelligencia integrálása a homologizációs és önellenőrzési folyamatba történelmi lehetőség, de sok erőfeszítést igényel. Annak érdekében, hogy az autonóm jármúvek megjelenhessenek a közúti közlekedésben, legalább olyan biztonságossá kell ezeket a jármúveket tennünk, mint a hagyományosakat. Ehhez a következő kulcsfontosságú területeket definiáltuk:

\section{Autonóm jármïpek környezettudatossága}

Az autonóm jármúvek elterjedésével a szenzorrendszerek és a környezet érzékelés, valamint a jármü irányítása. A kutatás célja a tényleges és az újonnan kifejlesztett autonóm rendszerek és azok forgalomra gyakorolt hatásainak vizsgálata, valamint az emberi vezetők és a korábbi rendszerek gyengeségein alapuló, az önvezetés legpontosabb és legmegfelelőbb önálló vezetési rendszereinek létrehozásához szükséges tényezők meghatározása. Ehhez szükséges olyan forgalmi helyzeteket meghatározni, amelyek problémákat okozhatnak az autonóm rendszereknél. Ezek alapján kialakított tesztkörnyezet segítségével keresni a megoldásokat a felmerült nehézségekre.

\section{A követett trajektóriák továbbfejlesztése}

$\mathrm{Az}$ autonóm jármúvekben alkalmazott algoritmusok mellett ez egy másik kulcsfontosságú terület. A járműdinamika tanulmányozásával jobb modellek hozhatók létre, és pontosabb megfelelő vezérlők fejleszthetők ki. A jármúdinamika jobb megértése és modellezése alapvető a szimulációk szerepének és megbízhatóságának növeléséhez, a valós életben történő tesztelés csökkentése érdekében. Az autonóm jármüvek normál forgalmi vizsgálati idejét csökkenteni lehet magas szintü és validált szimulációk kibővített és egyesített felhasználásával. Az APZ-vel, az autonóm jármúvek egyik legújabb tesztközpontjának szoros együttmúködésével, számos tesztterület fejlesztése - mint például városi övezetek, autópálya, vidéki utak - lehetséges szimulációs környezetben. Ezek lehetôvé teszik, hogy a szimulációk után valós adatok legyenek megszerezhetők a tesztelés során.

A cikkben ismertetett problémákat felismerve számos megoldás kerül beépítésre az önvezető jármüvek számára készült tesztpálya fejlesztése során. A tesztpálya nemcsak a járművek és a forgalom tesztjeinek széles skáláját kínálja a hagyományos, csatlakoztatott és automatizált járművekhez, hanem lehetséges prototípus-megoldások tesztelésére is, illetve a típusjóváhagyási eljárás fejlesztése és oktatási célokra is felhasználható (Szalay 2016).

A tesztpálya szerves részeként kiberbiztonsági tesztközpont is fejlesztés alatt áll. Az EU kiberbiztonsági tanúsítási keretrendszerének tagjaként kiberbiztonsági kritériumok és követelmények értékelési központja lehet.
Az új tesztközpont lehetővé tenné, illetve javítja az információcserét az ipar szereplői között, megosztja a bevált gyakorlatokat, képes elválasztani és tisztázni a kiberbiztonsági felelősséget (Kasper-Krasznay 2019). Ez egy komplett jármútesztelő és -érvényesítő központ az autóipari kiberbiztonsági funkciókhoz, nemcsak az ismert, hanem a nem ismert biztonsági résekre összpontosítva. Képes lesz arra, hogy dedikált teszteket dolgozzon ki az ismeretlen sérülékenységek és a potenciális új sebezhetőségek kiküszöbölésére.

\section{Összefoglalás}

A digitális államban az autóipar valamint az infokommunikációs technológiák összekapcsolódnak és várhatóan az autonóm jármúvekben integrálódnak. Az eltérő minősítési és tesztelési háttér miatt azonban szükséges új minősítési eljárások kidolgozása. Az egyik fókuszterület a biztonságkritikus rendszerek vizsgálata, amelyben az autóipar komoly hagyományokkal rendelkezik, míg az információs technológia más megközelítést alkalmaz.

Véleményünk szerint elengedhetetlen az AI jármúvek homologizációs rendszerének kidolgozása, amelybe az információs és kommunikációs technológia elemeit be kell ágyazni. Ezeknek a rendszereknek a létrehozása kiemelten fontos, mert megteremtik a kapcsolódást a közlekedés, a jármúipari és a digitális állam között. A két eltérő megközelítés együttes kezelésének kritikus tényezői a kiberbiztonsági rendszerek kezelése és a mesterséges intelligencia alapú rendszerek integrálása. Javaslatunk, hogy a felvetett kérdések megoldására egyedülálló válaszok kerüljenek kidolgozásra, amelyre a szakavatott kutatók és a speciálisan felkészített tesztpálya szoros együttmúködésében kerülhet a leghatékonyabban sor.

\section{Köszönetnyilvánitás}

A tanulmány alapjául szolgáló kutatást az Emberi Erőforrások Minisztériuma által meghirdetett Felsőoktatási Intézményi Kiválósági Program támogatta, a Budapesti Műszaki és Gazdaságtudományi Egyetem Mesterséges Intelligencia (BME FIKP-MI/FM) tématerületi programja keretében.

\section{Irodalom}

Csiszár, Cs. (2019) Demand Calculation Method for Electric Vehicle Charging Station Locating and Deployment, Periodica Polytechnica - Civil Engineering 63: 1 pp. 255-265. , 11 p. (2019)

Emőd, I., Tölgyessi, Z. \& Zöldy, M. (2006) Alternatív Jármúhajtások, Budapest, Maróti könyvkereskedés és könyvkiadó Kft, 232 p.

Goodfellow, I., Bengio, Y. \& Courville, A. (2016) Deep learning. Cambridge, MA, MIT press.

Grzywaczewski, A. (2017) Training AI for Self-Driving Vehicles: the Challenge of Scale, October 9, 2017. https://devblogs.nvidia. com/training-self-driving-vehicles-challenge-scale/

Kasper, A \& Krasznay, Cs. (2019) Towards Pollution-Control in Cyberspace: Problem Structure and Institutional Design in International Cybersecurity, International and Comparative Law Review 19: 2 pp. 76-96. Paper: 3, 20 p. 
Pinchon N., Khedher I., Cassignol O., Nicolas A., Bernardin F., Leduc P., Tarell J.P., Brémond R., Bercier E. \& Julien, G. (2016). Allweather vision for automotive safety: which spectral band? Oct. 2016, Proceeding of VISION SIA, https://www.researchgate. net/publication/309291304_All-weather_vision_for_automotive_safety_which_spectral_band

Rödönyi, G., Gáspár, P., Bokor, J. \& Palkovics, L. (2014) Experimental verification of robustness in a semi-autonomous heavy vehicle platoon, Control Engineering Practice 28: 1 pp. 13-25., 13 p.

Sabjanics, I. (2010) Az online oktatási forma alkalmazásának lehetősége a képzési struktúrában. Gazdasági élet és társadalom, pp. 157163., $7 \mathrm{p}$.

Szalay, Zs., Hamar Z. \& Nyerges, Á. (2019) Novel design concept for an automotive proving ground supporting multilevel CAV development. International Journal of Vehicle Design, 2019 Vol.80 No.1, pp. 1-22 10.1504/IJVD.2019.105061

Szalay, Zs. (2016) Structure and Architecture Problems of Autonomous Road Vehicle Testing and Validation. In: Proceedings of the 15th VSDIA 2016. Budapest, Hungary, pp. 229-236., (ISBN:978963-313-266-1)

Tettamanti T., Varga, I. \& Szalay, Zs. (2016) Impacts of Autonomous Cars from a Traffic Engineering Perspective, Periodica Polytechnica, Transportation Engineering, Hungary, 44(4), pp. 244-250, 2016, DOI: 10.3311/PPtr.9464

Wang, M., Cui, Y.R., Wang, X., Xiao, S., \& Jiang, J. (2018) Machine Learning for Networking: Workflow, Advances and Opportunities. IEEE Network, Vol 32, 92-99. 10.1109/MNET.2017.1700200 Zöldy, M. (2009) Automotive Industry Solutions in Response to European Legislative Emission Regulation Challenge, Science - Future of Lithuania / Mokslas - Lietuvos Ateitis 1: 6 pp. 33-40., 8 p.

Zöldy, M. (2016) Új kihívások előtt az autóipar a dízelbotrány után. In: Csibi, J., Fülöp, B. (szerk.) Országos Gépészeti Találkozó 2016, Nagyvárad, Románia: EMT, (2016) pp. 101-105., 4 p.

Zöldy, M. (2018) Investigation of autonomous vehicles fit into traditional type approval process. Proceedings of ICCTE 2018 Beograde, pp. 517-521. ISBN 978-86-916153-3-8 